\title{
Systematic Research on Strengthening the Teaching Content of "Ideological and Moral Cultivation and Legal Basis"
}

\author{
Ganzhong Jiang* \\ Hangzhou Normal University Qianjiang College, Hangzhou 310016, Zhejiang, China. E-mail: 953877773@qq.com
}

Abstract: "Ideological and moral cultivation and legal basis" is an organic whole with the socialist core value system as the core and the socialist core value system as the guide, which is highly systematic.

Keywords: Teaching Content; Ideological and Moral Cultivation and Legal Basis;Socialist Core Value System; Dialectical and Unified Organic Entirety

\section{Problem statement}

The ideological and moral courses named "ideological and moral cultivation" of 98 Plan "two courses" (ideological and moral courses and political theory courses) ${ }^{[1]}$ now are merged into "ideological and moral cultivation and legal basis" (hereinafter referred to as "basis") of the 05 plan (hereinafter referred to as "basis") ${ }^{[1]}$. It is the 15 th year since it was opened, and the teaching contents of the teaching materials are constantly revised in line with the changes of the situation and tasks of the Party and the country, and the ideological and political teachers also constantly sort out the systematicness of the teaching contents, but up to now, no mature teaching achievement has been published. It had systematically thought about the "basic" teaching content, now some immature views will be presented as the picture blow showed for discussion.

\section{The systematicness of teaching content of "ideological and moral cultivation and legal basis"}

\subsection{The core of the "foundation" teaching content is the socialist core value system}

The core of the "foundation" teaching content is the socialist core value system. "The decision of the Central Committee of the Communist Party of China on several important issues concerning the construction of a harmonious socialist society", emphasizes that it is fundamental to the construction of a harmonious culture when discussing the status of the Socialist Core Value System. It is the concentrated embodiment of the socialist ideology, the theoretical basis of the socialist ideological and moral construction and the spiritual bond that maintains the unity and amity of the Chinese nation and the spiritual force that inspires the Chinese nation to strive for progress ${ }^{[2]}$. Although the socialist core value system only occupies three sections of the four sections of the introduction, it represents the introduction and occupies the core position of the teaching content of the textbook ${ }^{[3]}$. The so-called core position is mainly reflected in two aspects: first, the socialist core value system leads the whole teaching content. On the one hand, the Socialist Core Value System guides the whole teaching content, not only in the socialist ideological and moral construction, but also in the legal construction. On the other hand, the whole teaching content is the ideological and 
moral, legal theory and practical basis of the socialist core value system. Second, the socialist core value system runs through all the teaching contents. The so-called transfixtion refers to the socialism core value system intrinsic four essential factors permeates in each teaching content, with no blank room leaved ${ }^{[3]}$. The guiding ideology of the eight chapters of "ideological and moral cultivation and legal basis" is derived from Marxism. The first chapter is about the common ideal of socialism with Chinese characteristics, and the chapter two is about the patriotic traditional national spirit embodies the quintessence of the national spirit with patriotism as its core and the spirit of the times with reform and innovation as its core. The third to eighth chapters teach the true meaning of life, the value of life, the moral character of moral cultivation, social morality, professional morality, family morality and legal spirit, etc. The teaching contents embody the basis of the "Eight Honors and Eight Shames"[2].

\subsection{The core value system of socialism includes four aspects}

The core value system of socialism includes Marxist guiding ideology, the common ideal of socialism with Chinese characteristics, the national spirit with patriotism as its core, the spirit of the times with reform and innovation as its core and the dialectical unity of the "Eight Honors and Eight Shames". They are an organic entirety, but their respective positions and roles are different. They are respectively the soul, theme, essence and foundation of the socialist core value system ${ }^{[4]}$, therefore, the four aspects of the socialist core value system correspond to the teaching contents of different chapters. As the soul of the socialist core value system, Marxist guiding ideology plays a theoretical guiding role in the teaching contents of the whole book, which is undoubtedly of great theoretical and practical significance for the ideological and moral construction and the legal construction to ensure the correct political direction. The vivid practice of ideological and moral construction and legal system construction provides the positive foundation and the power source for the development of Marxist theory ${ }^{[2]}$.

A systematic diagram of the contents of the "fundamentals" course is as follows: 


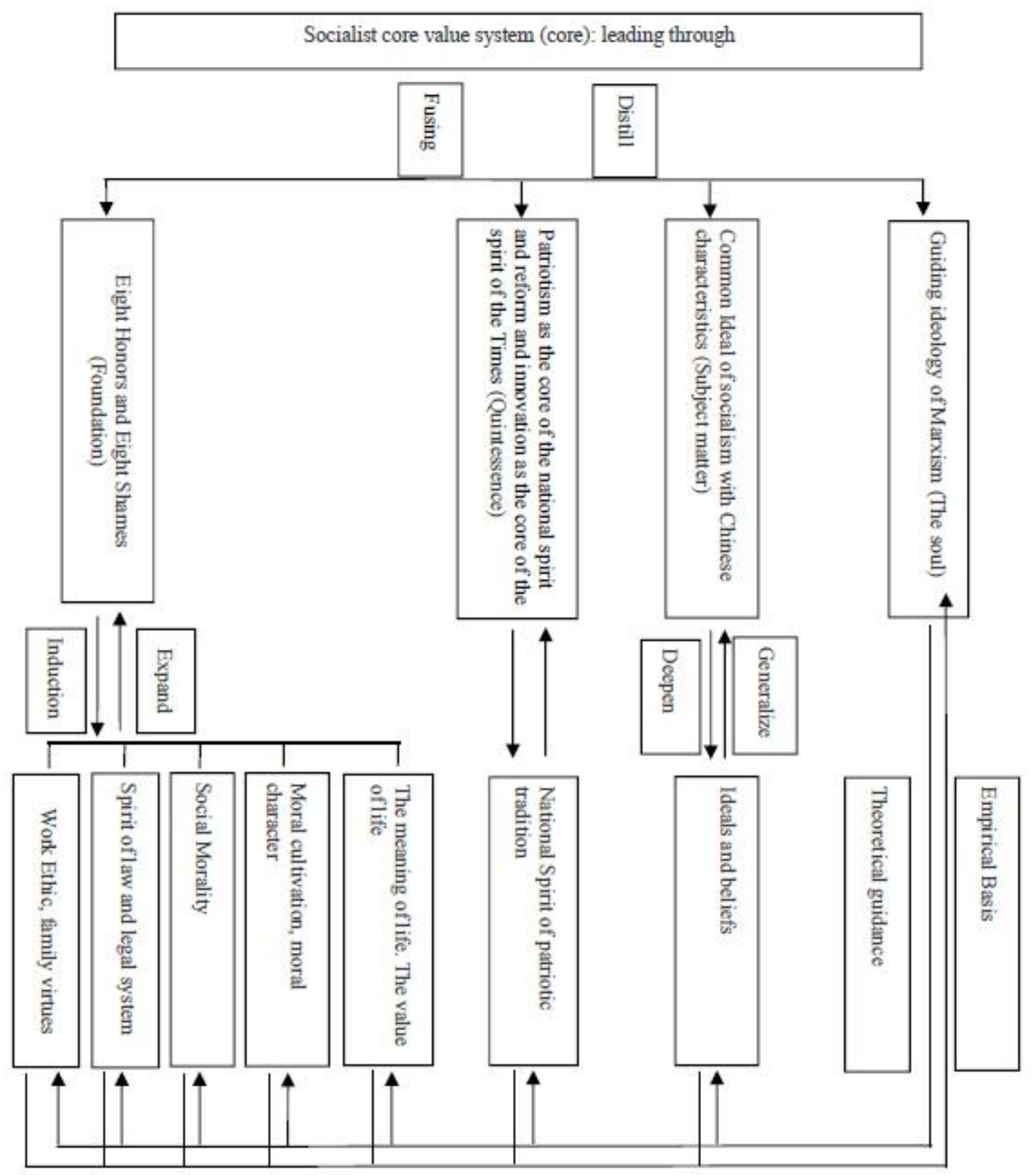

The common ideal of socialism with Chinese characteristics is the deepening of the ideal and faith in the chapter 1 , because the ideal and faith are multi-level and multi-category, and the common ideal of socialism with Chinese characteristics is the common aspiration and urgent demand of the whole Chinese people. The theme of the form of ideal and belief is the common ideal of socialism with Chinese characteristics ${ }^{[9]}$. The national spirit with patriotism as its core and the spirit of the Times with reform and innovation as its core plays an important role in the integration of the patriotic traditional national spirit in the teaching contents of the second chapter. It depends entirely on patriotism and reform and innovation, and in this complicated patriotic tradition and spirit of the era, the national spirit with patriotism at its core and the spirit of the times with reform and innovation at its core have been refined ${ }^{[2]}$. "Eight Honors and Eight Shames" is a summary of the teaching contents of the third to eighth chapters, including the true meaning of life, the value of life, moral character of moral cultivation, social morality, professional morality, family virtues, legal spirit and legal system. The expansion of "Eight Honors and Eight Shames" has formed the true meaning of life, life value, moral quality of moral cultivation, social ethics, professional ethics, family virtues, legal spirit and 
legal system.

\section{Conclusion}

In a word, the content of eight chapters of the teaching content of the "basic" course with the socialism coral value system as its core, is an organic entirety guided and penetrated by socialist core value system, equipped with the extraordinary systematicness.

\section{References}

1. Gu H. Review and prospect on the construction of ideological and political theory teachers since the reform and opening up (in Chinese). Ideological \& Theoretical Education 2008; (17): 6-12.

2. Writing Group. Ideological and moral cultivation and basic law education (in Chinese). China Higher Education Press; 2008. p. 75, 1-7, 35, 45-72.

3. Guo H. The core values of socialism at three levels and their internal relations (in Chinese). Guang Ming Daily 2013.

4. $\mathrm{Hu}$ J. Selected and compiled important documents since the 17th National Congress of CPC (in Chinese). Central Literature Publishing House; 2009. p. 26. 